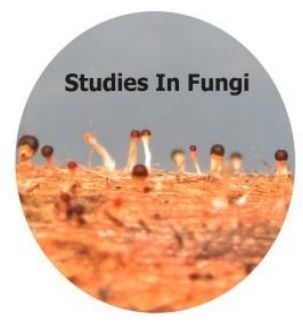

Studies in Fungi 2 (1): 106-111 (2017) www.studiesinfungi.org ISSN 2465-4973

Article

Doi 10.5943/sif/ 2/1/12

Copyright $(0)$ Mushroom Research Foundation

\title{
Occurrence of Stemonitis axifera (Bull.) T. Macbr. (Myxomycota: Stemonitales) in Pondicherry, a union territory of India
}

\author{
Keekan $K^{1}$ and Ranadive $K^{2}$
}

${ }^{1}$ Yenepoya Research Centre, Yenepoya UniversityUniversity Road, Deralakatte, Mangalore 575 018. Karnataka, India)
${ }^{2}$ Department of Botany, Waghire College, Saswad, Post-Saswad, Taluka-Purandar, Pune District, Pune- 412301,
Maharashtra, India

Keekan KK, Ranadive KR 2017 - Occurrence of Stemonitis axifera (Bull.) T. Macbr. (Myxomycota: Stemonitales) in Pondicherry, a union territory of India. Studies in Fungi 2(1), 106111, Doi 10.5943/sif/2/1/12

\begin{abstract}
Stemonitis axifera, observed on a piece of dead wood from Pondicherry, a union territory of India is described here based on morphological and microscopical characteristics. This observation is relevant due to the infrequency of records of Stemonitales in southern India, especially in a territory like Pondicherry, a union territory of India with no appreciable forest cover and low biodiversity.
\end{abstract}

Key words - Acellular slime mould - Biodiversity - Myxomycetes

\section{Introduction}

Myxomycetes or slime molds are fungus-like heterothallic organisms existing as macroscopic multinucleate diploid 'plasmodial stage' and the microscopic uninucleate haploid 'amoeboflagellate stage' (Clark \& Haskins 2016). These are mainly terrestrial organisms, found throughout the world in different ecosystems (Ing 1994, Liu et al. 2015) comprising of about 985 described species (Lado et al. 2003). The occurrence, distribution, and diversity of myxomycetes in different habitats in different countries including India were reported earlier (Stephenson et al. 1993, Hatano 2007, Rojas et al. 2014, Liu et al. 2015). The most exhaustive report on the myxomycetes in India is available at "Checklist of Myxomycetes from India" (Ranade et al. 2012). From India, the most reports of myxomycetes are confined to the western, northern and eastern states of India and very less or negligible from southern states, especially union territories. The different schemes of their classification were reported by Alexopoulos et al. 1996, Everhart \& Keller 2008, Stephenson 2011 \& 2014, Ruggiero et al. 2015, Liu et al. 2015). Stemonits Gled. (Chocolate tube slime; Tree hair; Pipe cleaner slime) is a myxomycete (Family: Stemonitidaceae) appearing brownish in color, cylindrical top portions (sporangia) and are supported by narrow, black stalks (Emberger 2008). The genus was first described by German botanist Johann Gottlieb Gleditsch in 1753 (Gottlieb 1753). The 2014 estimate suggests that there are 18 species in the genus (Doğan \& Eroğlu 2014). This report describes Stemonitis axifera (Bull.) T. Macbr. observed in Pondicherry, the capital city of Indian union territory of Pondicherry.

\section{The history of works}


The history of works on myxomycetes in India is given by Venkataramani \& Kalyanasundaram (1986). They also described the distribution of Stemonitales in relation to aspects such as altitude, temperature, and rainfall. Several (Ghosh \& Dutta 1963, Vasava et al. 2015) authors have studied the distribution/abundance of Stemonitales in India and concluded that the distribution of Stemonitales is not uniform throughout the country with southern India showing low numbers. Stemonitales are generally found on woody substrates in northwestern India, however, some species may be observed on a litter (Stephenson et al. 1993). The myxomycete of the present study was collected on dead wood. Stephenson et al. (1993) further states that the occurrence of the myxomycete Stemonitis axifera is occasional or rare in northwestern and southern India. Also, Agnihothrudu \& Chinnappa (1969) previously reported few myxomycetes from Southern India.

\section{Materials \& Methods}

\section{Sample collection}

The specimen was collected from a dead wood located within the Pondicherry University campus $\left(12^{\circ} 01^{\prime} 17.46^{\prime \prime} \mathrm{N} \mathrm{79} 51^{\prime} 12.61^{\prime \prime} \mathrm{E}\right)$, Pondicherry (or Puducherry, the local name) - the capital city of Indian union territory of Pondicherry (Fig. 1).

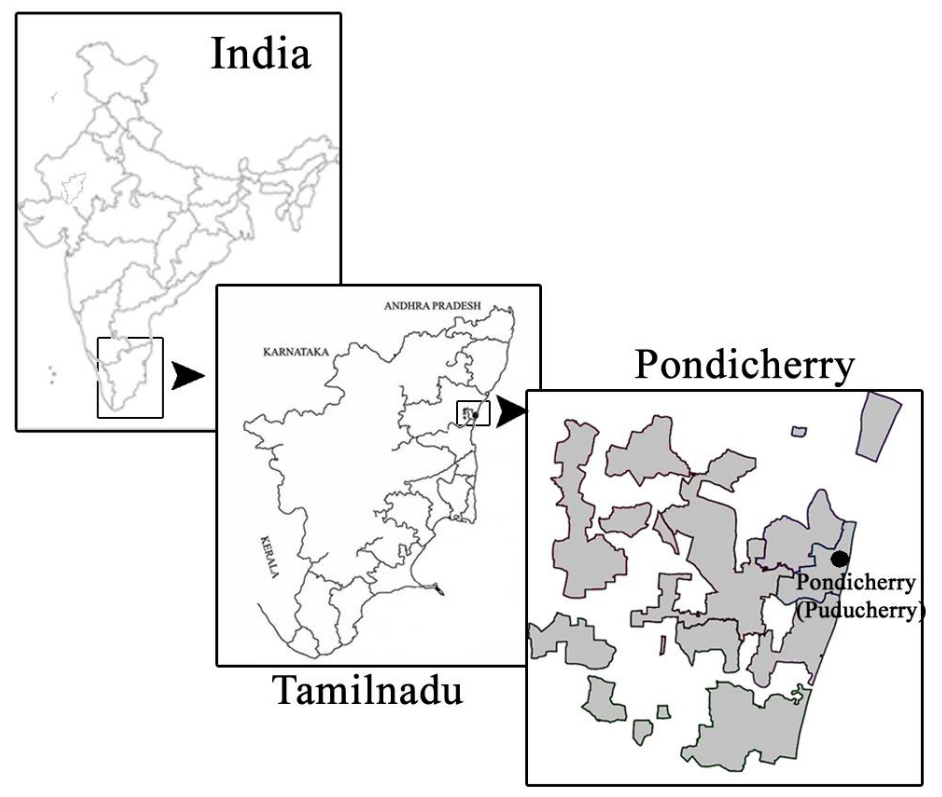

Fig. 1 - Map showing the location of specimen observation and collection at Pondicherry

The external characteristics of specimens were photographed using a Nikon Coolpix S220 camera (Nikon Corporation, Japan). The microscopic images were captured using a Motic BA310 digital binocular microscope with Digital microscopy software suite (Images Plus 2.0) (Motic, Hong Kong).

\section{Results}

\section{Taxonomy}

Stemonitis axifera (Bull.) T. Macbr., North American Slime Moulds: 120 (1889) [MB\#119956]

\section{Description}

The specimen was observed in small clusters on a dead wood located within the Pondicherry University campus. The fruiting body has distinctive reddish-brown sporangia, supported on slender stalks (Fig. 2). 

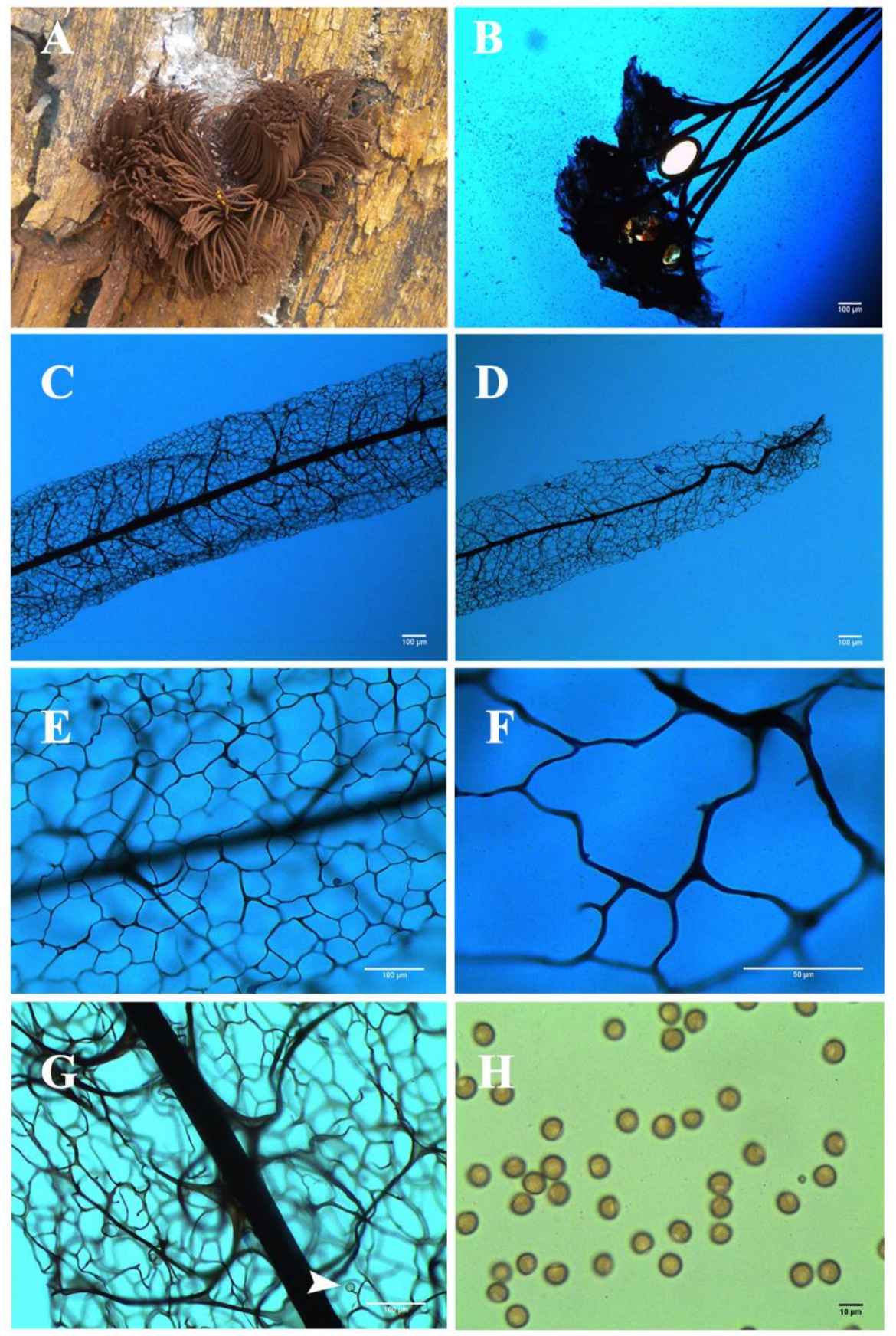

Fig. 2 - Fruiting bodies of Stemonitis axifera (Bull.) T. Macbr. On a dead wood A. bunch of stalks, B. Columella and Sporangium, C. Sporangium with acuminate apex, D. Capillitium - the mesh of internal network, E. Capillitium enlarged, F. Capillitium holding a spore (arrow head), G. Spores (H).

Fructification sporangiate, aggregated, stipitate, in medium size clusters, cylindrical, dark brown, acute or sub-acute apex. Sporocarps tufted, 10-15( 25) $\mathrm{mm}$ total height. Sporothecae (Sporangium) dark brown with a reddish tinge. Hypothallus silvery, shining, confluent. Stalk 1-4 mm long, shining black. Columella black, almost reaching the sporotheca apex, tapered and flexuous towards the tip. Capillitium dark brown/black and with a metallic glint, the primary branches arising obliquely to the columella expanded at the junctions within the net hardly branched thus only weakly supporting the surface net which usually collapses onto the columella soon after spore-dispersal, the mesh of internal network is angular, variable in size (ranges from $10-110 \mu \mathrm{m}$ in width). Spore mass was dark reddish brown to pale brown in color. Spores lilacbrown, globose, warted and smooth in some parts with $7-9 \mu \mathrm{m}$ in diameter. 


\section{Discussion}

The specimen of the present study was identified up to the species level as $S$. axifera based on the characters described for $S$. axifera from other parts of the world including India (Hatano 2007, Kharat \& Nanir 2010, Vasava et al 2015, Ranade \& Ranadive 2016). It is a common species found associated with decaying wood and can be distinguished by its bright rusty brown colored fruiting body/sporangia, occurring in small or medium-sized clusters (Phate and Mishra, 2014).

Earlier S. axifera was reported from Mahabaleshwar, (Maharashtra); Tindharia, Darjeeling, (West Bengal); Mussoorie, (Uttar Pradesh); Nazira, Tocklai, (Assam); Mandi, Simla, Narkanda, (Himachal Pradesh) (Ranade et al. 2012). Agnihothrudu (1954a, 1954b, 1955, 1956a, 1956b), Agnihothrudu \& Chinnappa (1966a, 1966b), Indira (1968a, 1968b, 1975), Stephenson et al. (1993) have studied the myxomycetes of southern India. However, the record of S. axifera in the southern part of India is not obvious due to the unavailability of sufficient literature. On the other hand, Stephenson et al. (1993) reported the occurrence/distribution of myxomycetes from Madras (now called Chennai) collected during 1954-1989. They observed eight isolates of Stemonitis in the Chennai study area, except S. axifera. Both Chennai and Pondicherry union territory is located in the south-eastern coast (Coromandel Coast) of South India, sharing almost the same climatic conditions. The vegetation is classified under tropical dry evergreen forests (Champion \& Seth 1968, Parthasarathy et al. 2008). Its biodiversity and conservation significances are discussed by Parthasarathy et al. (2008), Seshadri et al. (2012), Padmavathy \& Anbarashan (2013). The biodiversity of union territory is in various stages of degradation due to unregulated and unsustainable exploitation of forests and diversion of forest lands for non-forest usages, excessive use of pesticides, fertilizers, discharge of untreated sewage and industrial effluents etc (MeherHomji 1974, Rao \& Meher-Homji 1993, Stephen 2016). In this context, finding S. axifera in this ecologically sensitive, with no significant forest cover (only $13 \mathrm{~km}^{2}$ ) is important.

\section{References}

Agnihothrudu V. 1954a - Some slime-moulds from Southern India-I. Journal of the Indian Botanical Society 33, 171-181.

Agnihothrudu V. 1954b - Some slime-moulds from Southern India-II. Journal of the Indian Botanical Society 33, 182-188.

Agnihothrudu V. 1955 - Some slime-moulds from Southern India-Ill. Journal of the Indian Botanical Society 34, 85-91.

Agnihothrudu V. 1956a - Some slime-moulds from Southern India-IV. Journal of the Indian Botanical Society 35, 27-37.

Agnihothrudu V. 1956b - Some slime-moulds from Southern India-V. Journal of the Indian Botanical Society 35, 210-221.

Agnihothrudu V. 1959 - Notes of Fungi from North East India IV. Journal of Indian Botanical Society 38, 418-491.

Agnihothrudu V, Chinnappa CC. 1966a - Some slime-moulds from Southern India-VI. Sydowia. 20, 183-185.

Agnihothrudu V, Chinnappa CC. 1966b - Some slime-moulds from Southern India-VII. mycopathol. mycol. Appl. 38, 362-366.

Agnihothrudu V, Chinnappa CC. 1969 - Some slime-moulds from Southern India-VI. Mycopathologia et mycologia applicata 38(4), 363-366.

Alexopoulos CJ, Mims CW, Blackwell MM. 1996 - Introductory Mycology (4 ${ }^{\text {th }}$ Ed). John Wiely \& Sons. Inc. New York \& London.

Champion HG, Seth SK. 1968 - A revised survey of the forest types of India. Government of India Press, New Delhi

Clark J, Haskins EF. 2016 - Mycosphere Essays 3. Myxomycete spore and amoeboflagellate biology: a review Mycosphere 7(2), 86-101. 
Doğan HH, Eroğlu G. 2014 - A new Stemonitis species from Turkey. Mycotaxon 129 (2), $293-$ 296. http://dx.doi.org/10.5248/129.293

Emberger G. 2008 - Stemonitis sp. Messiah College. Available at http://www.messiah.edu/Oakes/fungi_on_wood/club\%20and\%20coral/species\%20pages/Ste monitis.htm (accessed 10 Jan 2017).

Everhart SE, Keller HW. 2008 - Life history strategies of corticolous myxomycetes: the life cycle, plasmodial types, fruiting bodies and taxonomic orders. Fungal Diversity 29, 1-16.

Ghosh GR, Dutta BG. 1963 - Myxomycetes from Orissa (India). III. Mycopathologia Et Mycologia Applicata 30(19), 271-82.

Gottlieb GJ. 1753 - Methodus fungorum. 1-162. pi. 1-6.

Hatano T. 2007 - A Study of Taxonomy and Distributions of Genus Stemonitis (Myxomycetes). International buddhist university bulletin 45, 289-311.

Indira PU. 1968a - Some slime-moulds from Southern India-VIII. Journal of the Indian Botanical Society $47,155-186$.

Indira PU. 1968b - Some slime-moulds from Southern India-IX (Distribution, habitat and variation). Journal of the Indian Botanical Society 67, 330-341.

Indira PU. 1975 - Some slime-moulds from Southern India-XI. Kavaka 3, 41-54.

Ing B. 1994 - Tansley review no. 62 The Phytosociology of myxomycetes. New Phytol 126,175201.

Kharat GT, Nanir SP. 2010 - The Myxomycetes of Pachmarhi Hills (India) - I. Bionano Frontier. $3(1), 118-122$.

Lado C, Estrada-Torres A, Stephenson SL, Wrigley-de Bessanta D, Schnittler M. 2003 Biodiversity assessment of myxomycetes from two tropical forest reserves in Mexico. Fungal Diversity 12, 67-110.

Liu Q, Yan S, Chen S. 2015 - Species diversity of myxomycetes associated with different terrestrial ecosystems, substrata (microhabitats) and environmental factors. Mycological Progress 14, 27.

Meher-Homji VM. 1974 - On the origin of the tropical dry evergreen forest of South India. International Journal of Ecology Environmental Science 1, 19-39.

Padmavathy A, Anbarashan M. 2013 - Biodiversity of coastal Lagoon in Nallavadu village, Puducherry, India. International Journal of Biodiversity and Conservation. 5(1), 33-38.

Parthasarathy N, Arthur Selwyn M, Udayakumar M. 2008 - Tropical dry evergreen forests of peninsular India: ecology and conservation significance. Tropical Conservation Science. 1(2), 89-110.

Phate P, Mishra R. 2014 - First Report on Spore to Spore Agar Culture of Stemonitis axifera (Bull.) T. Macbr. From Maharashtra, India. India Indian Journal of Applied Research. 4(11), 82-84.

Ranade VD, Korade ST, Jagtap AV, Ranadive KR. 2012 - Checklist of Myxomycetes from India Mycosphere 3(3), 358-390.

Ranade VD, Ranadive KR. 2016 - Flora of the Myxomycetean fungi from western Maharashtra, Universal Publisher, Pune. pp. 142.

Rao TA, Meher-Homji VM. 1993 - Dry coastal Ecosystem of the Indian sub-continent and islands. In: Van der Maarel E (ed.) Ecosystem of the World. 2B. Dry Coastal Ecosystems: Africa, America, Asia and Oceania. Elsevier, Amsterdam, pp. 151-164.

Rojas C, Rollins AW, Stephenson SL. 2014 - Distribution of myxomycetes among the microhabitats available for these organisms in tropical forests. In Misra JK, Tewari JP, Deshmukh SK, Vágölgyi C (eds). Fungi from different substrates. CRC Press, Florida.

Ruggiero MA, Gordon DP, Orrell TM, Bailly N, Bourgoin T, Brusca RC. 2015 - A higher level classification of all living organisms. PLoS ONE 10(4): e0119248.

Seshadri KS, Chandran AV, Gururaja KV. 2012 - Anurans from wetlands of Puducherry along the East Coast of India. Check List 8(1), 023-026.

Stephen KRJ. 2016 - Environmental issues of Puducherry UT an environmentalist's outlook. BEST: International Journal of Humanities, Arts, Medicine and Sciences. 4(4), 171-196. 
Stephenson SL, Kalyanasundaramt I, Lakhanpal TN. 1993 - A comparative biogeographical study of myxomycetes in the mid-Appalachians of eastern North America and two regions of India. Journal of Biogeography 20, 645-657.

Stephenson SL. 2011 - From morphological to molecular: studies of myxomycetes since the publication of the Martin and Alexopoulos (1969) monograph. Fungal Diversity 50, 21-34.

Stephenson SL. 2014 - Excavata: Acrasiomycota; Amoebozoa: Dictyosteliomycota, Myxomycota In McLaughlin DJ, Spatafora JW (eds), The Mycota- Systematics and Evolution, VII Part A, 2nd Edition. Springer-Verlag Berlin Heidelberg, pp. 21-38.

Vasava AM, Koyani RD, Singh AP, Rajput KS. 2015 - Diversity and distribution of myxomycetes in western part of India, with special reference to the state of Gujarat. Current Research in Environmental \& Applied Mycology 5(4), 382-389.

Venkataramani R, Kalyanasundaram I. 1986 - Distribution and ecology of myxomycetes in India. Proceedings of the Indian Academy of Sciences (Plant Science) 96(4), 289-301. 